\title{
Big Data Analysis of Sustainable Tourism Competitiveness in East Java Province
}

\author{
Dias Satria \\ Universitas Brawijaya, Indonesia \\ dias.satria@ub.ac.id \\ Joshi Maharani Wibowo \\ Universitas Surabaya, Indonesia \\ joshiwibowo@staff.ubaya.ac.id
}

East Java Province is known as one of Indonesia's regions that has succeeded in increasing their regional economic growth through tourism activities. The study's aim was to analyse East Java Province's sustainable tourism competitiveness potential using review data from the TripAdvisor website in 2019. TripAdvisor reviews are examples of big data for qualitative research that provide information about particular tourism competitiveness, like demographic condition, destinations characteristics, and tourism preference. This research chooses three tourism destinations with high competitiveness in East Java, namely: Jatim Park 2, Ijen Crater, and Bromo, Tengger, and Semeru National Park (B TSNP). Tourism activity in East Java has high competitiveness and sustainability. This research found that the sustainable tourism activity with high competitiveness can not only be applied to nature-based tourism destinations, such as Ijen Crater and в TSN P but also to artificial tourism like Jatim Park 2. Suppose the related stakeholders can explore and manage them well. In that case, tourism activity in East Java Province can extend tourist spending, their length of stay and finally increase regional income in East Java. To accomplish this goal, we provided four recommendation to related stakeholders in the shape of strategic policies to increase competitiveness capability and economic activity in the East Java Tourism Area. These are the following four strategies: tourism business levelling, local common tourism brand-enhancing, local tourism integration, and cashless transaction promotion.

Keywords: big data, tourism competitiveness, East Java, sustainable tourism

(cc) BY-SA https://doi.org/10.26493/2335-4194.14.189-203

\section{Introduction}

The tourism sector has been one of the relatively stable sectors in regional economic growth, especially in the 4.0 industrialization era (Industry 4.0 era). There are a group of young people called 'millennial travellers', known to have a significant role in provoking tourism activity (Poerwanto \& Shambodo, 2020). Subarkah (2018) also declared that millennial travellers significantly contribute to the regional economy about 101 USD to 500 USD by visiting tourism destinations around the particular area. The Ministry of Tourism and Creative Economy of Indonesia (2020) measured the high demand from the millennial generation in Indonesia, roughly about $5.5 \%$ or 2.8 billion Rupiah of the Indonesia National Gross Domestic Product (GDP). The related stakeholders, especially the gov- 
ernment, are trying to develop many potential sites into tourism destinations to meet that demand. One of the Indonesian regions that is intensively developing many possible areas into tourism sites is East Java Province.

In this province, the tourism industry is known as 'The Awakening Giant,' because East Java has a massive amount of natural and social resources that can be turned into tourism activity to attract suitable investors (Ministry of Communication and Informatics, 2019). Therefore, most cities and suburbs in East Java Province have their own local tourism destinations to increase their local economic growth, such as Jawa Timur Park, an amusement park in Batu City, or Purwodadi Botanical Garden in Pasuruan Regency. Besides local tourism destinations, several tourism destinations are developed and promoted in the international tourism market, such as: Bromo, Tengger, Semeru National Park (B T SN P) and Ijen Crater. These two destinations are mentioned in the Medium-Term National Development Plan 2020-2024 as two of ten Indonesia priority tourism destinations.

The tourism sector growth in East Java Province was shown from East Java overseas visit data through Juanda International Airport and Room Occupancy Rates of star hotels data in East Java. In March 2019, foreign tourist visits to East Java Province increased by $22.8 \%$ (21,565 visits) from February-March 2019 (17,561 visits). The Room Occupancy Rate of star hotels also showed growth by $0.82 \%$ in March 2019 (Central Statistics Agency of East Java Province, 2019). To anticipate and utilize the growth of tourism sectors in East Java, the regional government has tried to develop East Java Province tourism activity using a cluster system. Based on the Presidential Regulation of the Republic of Indonesia in Article 80 year 2019, the development of East Java tourism activity was divided into two cluster areas, which are the Bromo-Tengger-Semeru (в т s) Priority Area and Ijen Supportive Circular Area, as stated.

East Java Province tourism sector development was centred in the в тs priority area as the core area. This area has a high potential for nature-based tourism, such as ecotourism, agrotourism, educational tourism, and marine tourism. The development of the в т s pri-

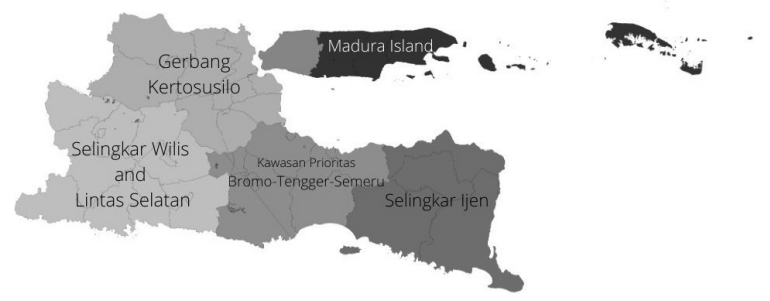

Figure 1 Priority and Supportive Area of East Java Province Map

ority area as a tourism site was supported by the Ijen Supportive Circular Area. Ijen Supportive Circular Area has a similar demographic to the в тs priority area and is famous as a tourism site because it has three tourism destinations known as Segitiga Berlian (The Triangle of Diamond). These three destinations are Ijen Crater, Sukamade Beach, and Plengkung Beach (G-Land). Besides these three main destinations, Ijen Supportive Circular Area also has various terrestrial reliefs that could potentially become tourism areas, like highlands, mountain ranges, volcanoes, hills (Ijen and Raung Mount), and lowlands and coasts (Suhato, 2016).

The development of the Ijen Supportive Circular Area was undertaken to support the в тs priority area by attracting tourists that visit Bali Island to visit tourism sites in East Java Province (Bank Indonesia, 2020). To accomplish that goal, the related government has tried to develop new tourism destinations around в тs and Ijen, such as Marina Boom in Banyuwangi Regency or Edelweiss Village in Wonokriti Village (Nanda, 2018; Wibowo et al., 2019). By developing tourism potential in East Java Province, the related government is not only aiming for regional economic growth but also economic equity in East Java Province rural areas.

One city that successfully grew as a modern tourism industrial area in East Java is Batu City. Batu City successfully developed its area through tourism activity and positively impacted the local community's 
economy by allowing them to participate in voluntary activities, like maintaining cleanliness, security, and tourism destination promotion (Nurhayati, 2009). One of the most favoured tourism destinations in Batu City is Jatim Park (Jawa Timur Park), especially Jatim Park 2. Jatim Park 2, also known as Batu Secret Zoo, is a tourism destination in East Java Province recommended by TripAdvisor as one of Batu City's must-visit tourism destinations (TripAdvisor, 2020a). Not only that, many positive reviews from local communities and visitors to Jatim Park 2 also support this fact through word-of-mouth promotion (Aprilia et al., 2015). According to this fact, Jatim Park 2 is known as an ideal artificial tourism destination that has positively influenced the East Java community's social and economic environment.

Based on the case of Jatim Park 2 reviews in TripAdvisor, we can conclude that social media has a high impact on tourism sectors. Suanpang (2020) and UNWTO (2020) also stated that social media such as TripAdvisor, Instagram, and Facebook played an important role in tourism competitiveness in 2020. This phenomenon happened because many visitors tried to tell other people about their experience at some tourism sites using social media. These experiences, written in social media, are called 'tourism reviews' and cover tourism destination competitiveness such as accessibility, facilities, and environmental conditions (Xiang et al., 2017). Many people can access these reviews and use them for many purposes like accommodation preference or government policy consideration. By using them for research purposes, tourism reviews can be classified as specified big data because textual-style data like social media reviews can represent the emotions, perspective, and feelings of a visitor during their visit to specific tourism destinations ( $\mathrm{Li}$ et al., 2018).

According to previous research, social media reviews can influence tourism destinations' competitiveness. Menk et al. (2018) and Schuckert et al. (2015) stated that social media positively impacts tourism destination competitiveness through data exploration. The potential consumers (travellers) usually do some online research before visiting a particular destination based on their preferences. Using social media, po- tential visitors try to find their preferred tourism site based on their budget and provided activity (Giglio et al., 2019). If stakeholders like the government or local communities can process this data very well, they can use it to make appropriate and suitable tourism development strategies. For example, nature-based ecotourism needs tourism strategy and activity to increase tourism and the economy. Still, it needs to have a low negative impact to avoid exploiting the ecological environment and social capital around tourism destinations (Sunardi et al., 2019).

Based on that fact, this research was conducted to observe East Java Province tourism sustainable competitiveness using social media TripAdvisor review data in 2019. This study focused on three major tourism destinations: Bromo Tengger Semeru National Park (в т SN P), Ijen Crater, and Jatim Park 2. All three destinations were selected due to their appearance in the top 15 TripAdvisor-recommended tourism destinations in East Java, their positive impact on the local community, and site location (President of the Republic of Indonesia, 2019; TripAdvisor, 2020b). The result of this research is expected to support related parties in maximizing East Java tourism competitiveness. By maximizing tourism competitiveness in East Java Province, in the near future, tourism sectors will come back and give the positive economic impact to East Java regional GDP and can be counted as one potential sector with a high resilience and growth after Covid-19 era.

\section{Literature Review}

\section{Sustainable Tourism}

Sustainable tourism is a tourism activity that integrates economic activity with social and natural capital around the destination (Tsaur et al., 2006). The tourism destination, from this perspective, should include local cultural identity as the main attraction without sacrificing tourist protection, satisfaction, and the environment around the destination. That is why sustainable tourism activity development should be undertaken based on socio-economic aspects following regional and national economic development growth in the destination area (Pavlic et al., 2019). Most of the time, sustainable tourism development in 
particular destinations was undertaken as a regional or national sustainable development policy project. The related stakeholder tried to preserve biodiversity and social capital in the surrounding area through sustainable tourism activity. Sustainable tourism activity also positively impacts the local community in social and economic sectors by increasing their income, and reducing poverty and the unemployment rate around tourism destinations (Tung \& Cuong, 2020).

For some time, economic and social impacts on local people have been considered as tourism destination long-term guarantees to maintain tourism activity and tourist satisfaction at tourism sites (Nestoroska, 2012). The concept of a sustainable tourism destination is known to maintain tourist satisfaction for returning and newcomer tourists due to their management trying to provide diverse experiences and satisfy tourists. The sustainable tourism concept is commonly known as a tourism management commitment to managing all kinds of resources in destination areas for the economy, and social, and environmental purposes (Hassan, 2000). This commitment is represented in management, tourist, and government acts to preserve local culture, ecological cyclic processes, biodiversity, and other life support systems. Sustainability in tourism sites can only be achieved when every stakeholder, including tourists and local communities, can actively participate in sustainable activities and destination decision-making. This activity will positively enhance the tourism activity experience and raise sustainable tourism awareness for tourists, local communities, and other related stakeholders (Sasidharan \& Krizaj, 2018; Wibowo et al, 2019).

\section{Digital Tourism}

Digital tourism, or e-tourism, is known as the integration of Information and Communication Technology (ICT), especially the internet, in the tourism industry (Yanti, 2019). Putra et al. (2018) stated that tourism destinations could be introduced digitally to improve their competitiveness by creating content and spreading it digitally through social media, websites, television, or another digital platform. This method, called 'try-before-you-buy' can help tourist candidates to get a more realistic experience before deciding to visit a particular destination (Gretzel et al., 2020; Heliany, 2019). In exchange, the related stakeholders can promote their destination in a broader range but with lower cost and more targeted traffic (Putra et al., 2018; Yanti, 2019).

Indonesia's government considers digital tourism as a promotion strategy to improve Indonesian tourism competitiveness among domestic and overseas tourists (Putra et al., 2018). To realize that purpose, the Indonesia Ministry of Tourism and Creative Economy applied three main policies: Wonderful Startup Academy, Nomadic Tourism, and Destinasi Digital (digital destination) (Heliany, 2019). Through that programme, the government and stakeholders could communicate and maximize the implementation of all three main programmes to improve Indonesia's economic growth through the tourism sector. This policy implementation has also been followed by a new supporting policy related to tourism destination business licenses owned by stalls around tourism destinations, tourism information accessibility, and other tourism activities.

\section{Tourism Competitiveness}

Tourism competitiveness is known as the capability to attract tourists to visit and revisit a particular tourism destination. The tourist revisit is one aspect of the tourism destination competitiveness to maintain their popularity in the tourism industry (Chin et al., 2014). The parameters to measure tourism competitiveness are environmental, social, cultural, political, and technological aspects (Blanco-Cerradelo et al., 2018). Tourism competitiveness measurement is taken to determine the impact of tourism factors, such as hospitality, commonwealth improvement, and local community education level, especially sustainable tourism awareness among youth of a particular destination (Blanco-Cerradelo et al., 2018; Minciu et al., 2010). By analysing these various factors, the management party might determine a proper strategy to improve the destination's competitiveness, for example, by making an adequate branding that is easily recognized, like 'Wonderful Indonesia,' the iconic tourism branding from Indonesia (Chen et al., 2016).

Sunaryo (2013) states there are many components 
that can be used to measure tourism competitiveness. Blanco-Cerradelo et al. (2018) measured tourism destination competitiveness based on destination attraction, welfare, and sustainability in their research. Zhang et al. (2011) described that tourism competitiveness could be measured based on tourist demand and supply in the tourism market. In Indonesia, there are five main parameters used to measure local tourism competitiveness. The parameters consist of attraction, accessibility, supporting facilities, information and communication, and institutional (Sunaryo, 2013).

\section{Big Data}

Big data is classified as large-scale heterogeneous data that increases every day and consists of various types of data (Sowmya \& Suneetha, 2017). Praveen and Chandra (2017) classify big data into three types: structured, unstructured, and semi-structured. Due to its data variance, big data is managed through specific processes as needed in research. If big data were mismanaged through an improper process, the data would be useless for research purposes (Kusumasari \& Rafizan, 2018). Tourism research usually uses structured data from social media data like reviews, posts, and comments because this data has a unique characteristic that is needed for academic purposes (Praveen \& Chandra, 2017).

In previous research, big data was used to determine tourism competitiveness through tourist experience reviews (Xiang et al., 2017). Many studies state that social media data is more accurate than questionnaire data for tourism research because the respondents write the review based on their experience when visiting the destination (Aydin, 2020; Sabiote-Ortiz et al., 2016; Sun et al., 2016). The other advantage of using social media data is that almost all of the social media data (reviews, photos, status, etc.) were written at that moment or almost in real-time by the user (Mohamed \& Al-Jaroodi, 2014).

The big data paradigm in tourism research is frequently formed as a framework of the smart tourism destination. This framework consists of three steps, namely data collection, interconnectivity, and data analysis. Through this big data framework, the study result is applied to establish new physical infrastruc- ture, social networking, and business model strategies to enhance the efficiency of destination competitiveness and increase the positive value of tourism activity to the related stakeholders (Gretzel et al., 2015).

\section{Methods}

This research was done through a qualitative approach consisting of data collection, analysis, and interpretation through observation (Hussein Jaddou, 2007). This research data was analysed based on the sentiment analysis concept using 'NVIVo 12' tools.

Through NVIvo 12, the data was classified and mapped into the specific topic based on the sentiment approach (positive, negative, and neutral). The result of the sentiment analysis processed data was used to describe the research result clearly as needed (Ye et al., 2009).

This study uses secondary data of BTSNP, Ijen Crater, and Jatim Park 2 tourist reviews from TripAdvisor in 2019. This data was collected using the text mining method, which is a method to gather valuable information for analysis purposes. This type of analysis is applied to collect precise and explicit information that is briefly preserved to be analysed using a computer or manually analysed by the researcher (Sari, 2020).

The study aimed to present a recommendation about tourism development policy that promotes the competitiveness, uniqueness, and inclusivity of East Java Province. Figure 2 shows the flowchart of methods to achieve this objective. First, East Java Province tourism was identified comprehensively through the text mining method by the researcher. Then, after the potential tourism competitiveness was recognized, we tried to provide a recommendation policy based on destination potential that can be considered and applied to increased East Java tourism competitiveness in the future.

\section{Results and Discussion}

\section{East Java Tourism Profile}

We obtained 640 reviews written in 2019 related to в T SN P, Ijen Crater, and Jatim Park 2 tourism destinations through the TripAdvisor site that can be classified as structured big data. Table 1 shows that the Ijen 


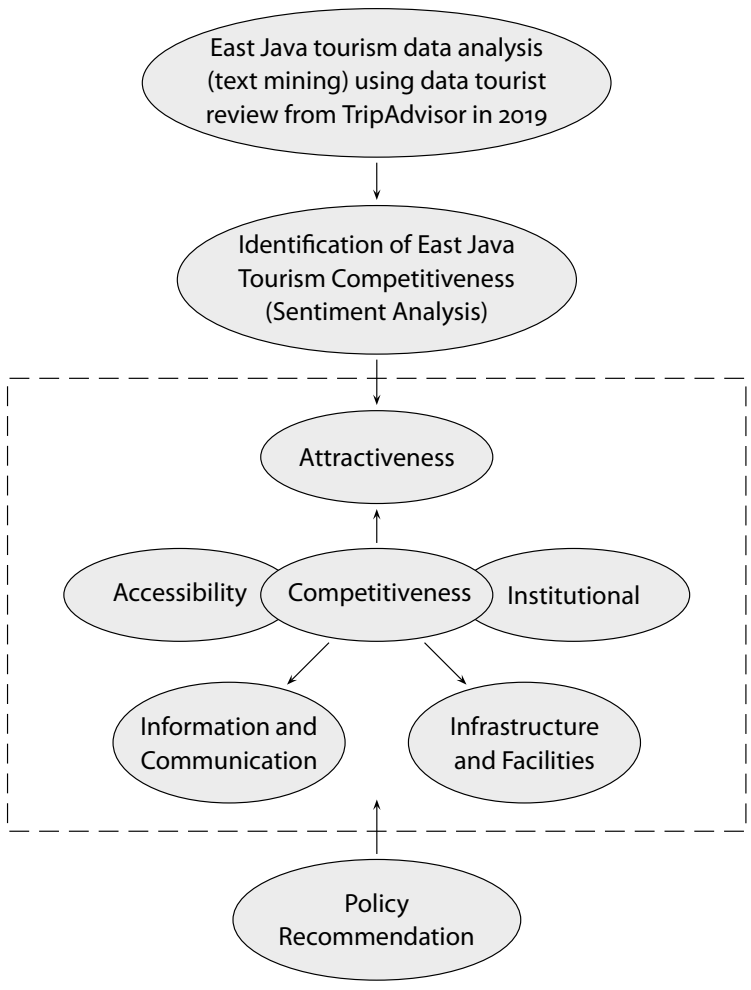

Figure 2 Conceptual Mindmap Flowchart

Crater was the most demanded tourism destination of East Java Province because Ijen Crater has the most reviews ( 245 reviews) in 2019, followed by Jatim Park 2, and finally в TSNP. Table 1 also shows that artificial tourism destinations like Jatim Park 2 have high competitiveness with the other nature-based tourism destinations in East Java because Jatim Park 2 has more reviews (205 reviews) than B TSNP (190 reviews).

Domestic tourists dominated high demand in East Java tourism activity. Table 2 represents Indonesia as the country with the most people visiting tourist sites in East Java Province, followed by Singapore, France, Malaysia, and Italy. Most domestic tourists in East Java Province came from outside provinces, such as from DKI Jakarta Province (from Jakarta City and Tangerang City) or Yogyakarta Province. The low rate of local East Java tourists shows a lack of interest in East Java tourism. Therefore, tourism competitiveness in East Java should be improved to meet the local tourists' needs and interests.
Table 1 East Java Tourism Reviews

\begin{tabular}{|c|c|}
\hline Destination & Number of reviews \\
\hline BTSNP & 190 \\
\hline Ijen Crater & 245 \\
\hline Jatim Park 2 & 205 \\
\hline Total & 640 \\
\hline \multirow{2}{*}{\multicolumn{2}{|c|}{$\begin{array}{l}\text { Notes Table } 1 \text { shows analysis from text mining processec } \\
\text { data related to the B TSNP, Ijen Crater, and Jatim Park } \\
\text { tourism destinations on the TripAdvisor website in } 2019 \\
\text { This data represented Ijen Crater as the most demandec } \\
\text { tourism destination of East Java Province, followed by the } \\
\text { Jatim Park } 2 \text { and B TSNP tourism destinations. } \\
\text { Table } 2 \text { Countries and Cities with Most Number of East } \\
\text { Java Province Destination Reviews }\end{array}$}} \\
\hline & \\
\hline Country or city & Number of Reviews \\
\hline Indonesia & 290 \\
\hline Jakarta & 89 \\
\hline Malang & 27 \\
\hline Surabaya & 24 \\
\hline Tangerang & 14 \\
\hline Yogyakarta & 14 \\
\hline Batu & 13 \\
\hline Bali & 8 \\
\hline Bogor & 8 \\
\hline Banyuwangi & 7 \\
\hline Bekasi & 6 \\
\hline Singapore & 33 \\
\hline France & 26 \\
\hline Malaysia & 15 \\
\hline Italy & 13 \\
\hline
\end{tabular}

The high interest of outside East Java Province tourists shown in Table 2 was followed by another find. We found evidence that many tourists, especially domestic tourists, only spent their time visiting one of the three East Java tourism destinations before returning or taking a trip to another tourism destination outside East Java Province, like Bali Island. Figure 3 shows a map of tourism mobilization across Bali and Java Islands in 2019. According to this figure, we can assume Bali-Java tourists usually travel directly from Bali to 


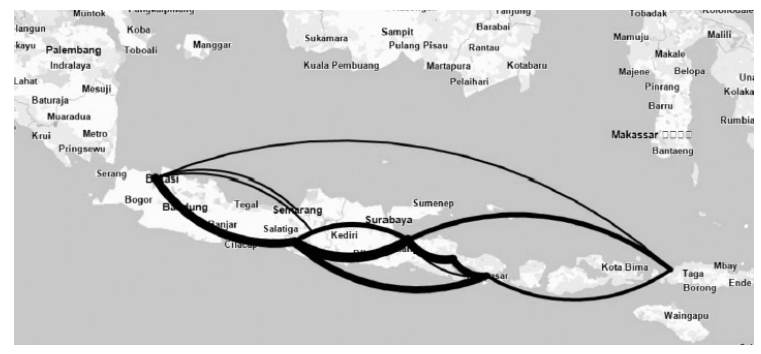

Figure 3 Java and Bali Island Tourism Mobilization in Indonesia

Yogyakarta, without visiting most of the tourism destinations in East Java. Despite the number of Ijen tourist visits, most of the tourists did not bother to visit other destinations like в passed through East Java Province.

Figure 3 shows most of the tourists skipping the leading tourism destination in East Java province. This evidence indicates that most East Java tourism destinations have lower tourism competitiveness than Yogyakarta and Bali Island. Asian and European tourists preferred to visit Yogyakarta and Bali Island instead of tourism destinations in East Java due to limited visit duration, lack of easy accessibility, insufficient supportive facilities, and low safety and health assurance. These weaknesses were commonly mentioned by tourists visiting East Java tourism destinations, especially tourism destinations in rural areas such as B TSNP. This weakness needs to be evaluated to identify East Java tourism competitiveness further and recommend a suitable policy. Thus, the policy is expected to support East Java tourism development with its distinct geographic condition, infrastructural capacity, and tourist and community needs in 2021.

\section{Identification of East Java Province Tourism}

Competitiveness through Perspective Analysis

A single data or tourist review in TripAdvisor could be classified as more than one category label of tourism competitiveness factors (accessibility; attraction; information and communication; institutional and supportive facilities). One review about the particular destination in TripAdvisor usually consisted of many things that can be classified in various aspects of East Java tourism competitiveness, thus it must not be sep- arated. Thereby, the number of data after being processed in the coding step usually has more data than the actual reviews data (640 reviews) (Table 3) (Rachmat \& Lukito, 2016). Aside from that, the analysed perspective review was determined as a single labelled perspective (positive, neutral, or negative) (Bandur, 2016).

Table 3 shows the result of TripAdvisor reviews data after being processed through coding and sentiment analysis in NVIVO 12. The result shows that Ijen Crater is the most influential tourism destination in East Java Province tourism competitiveness compared to Jatim Park 2 and в TSNP. This interpretation was obtained from a comprehensive review analysis of coding data processing. The more particular tourism destination was review data was processed in coding step, then the more likely the tourist could share their experience about that tourism destination (with positive, neutral, or negative sentiments). In contrast, в т SNP had a low data processed in coding step, representing tourists' low enthusiasm to review в TSNP.

The results of the sentiment analysis processing data and interpretation in East Java tourism competitiveness will be explained based on five tourism competitiveness parameters below.

\section{Accessibility}

Accessibility of a tourism destination includes the transportation route support system, station, airport, harbour, and other types of transportation existence (Sunaryo, 2013). Based on reviews in TripAdvisor, accessibility significantly harms B TSNP competitiveness.

There are 54 reviews or $45.76 \%$ negative reviews related to Ijen Crater accessibility and 13 reviews or $31.70 \%$ negative reviews related to B TSNP accessibility. Many tourists write that the Ijen Crater and B T SNP have poor lighting conditions, and incomplete paving, with a form of zig-zag and uphill routes. This condition can be considered dangerous for new tourists, especially because almost all of the BTSNP and Ijen Crater tourism activities are done at night. The study showed that 151 of 245 reviews came from tourists that had taken trips to Ijen Crater at $1 \mathrm{am}$. A similar condition was founded at B TSNP. There are 178 of 190 re- 
Table 3 East Java Tourism Competitiveness based on Sentiment Analysis

\begin{tabular}{|c|c|c|c|c|c|c|c|c|c|}
\hline \multirow[t]{2}{*}{ Parameter } & \multicolumn{3}{|c|}{ BTSNP } & \multicolumn{3}{|c|}{ Jatim Park 2} & \multicolumn{3}{|c|}{ Ijen Crater } \\
\hline & (1) & $(2)$ & (3) & $(1)$ & $(2)$ & (3) & $(1)$ & $(2)$ & (3) \\
\hline Accessibility & 7 & 21 & 13 & 3 & 11 & 6 & 15 & 49 & 54 \\
\hline Attraction & 145 & 30 & 2 & 158 & 28 & 10 & 173 & 40 & 6 \\
\hline Information and Communication & 24 & 35 & 11 & 35 & 46 & 7 & 41 & 101 & 23 \\
\hline Institutional & 12 & 7 & 6 & 5 & 1 & 2 & 26 & 34 & 8 \\
\hline Supportive Facilities & 14 & 42 & 14 & 91 & 19 & 6 & 30 & 80 & 11 \\
\hline Total & \multicolumn{3}{|c|}{383} & \multicolumn{3}{|c|}{428} & \multicolumn{3}{|c|}{691} \\
\hline
\end{tabular}

Notes Column headings are as follows: (1) positive, (2) neutral, (3) negative. Table 3 shows analysis results from the coding sentiment analysis process in positive, neutral, and negative reviews based on B T SNP, Ijen Crater, and Jatim Park 2 tourism destination reviews from TripAdvisor 2019. The total number of coding and processed reviews was more than the actual total reviews (640 reviews) in Table 1 . But the sentiment analysis result was the same with data from the coding process because every single review is only labelled once based on their sentiment characteristic.

views written by tourists who took trips at $0-2$ am in BTSNP.

The poor accessibility of both destinations is reducing the East Java tourism competitiveness. The poor road infrastructural condition is harmful to tourists with private vehicles, like a motorbike. This condition is worsened by the infrequent schedule of public transportation, even in the day. Most of the tourists try to overcome these obstacles by hiring the service of a travel agency. However, tourists need to pay more for travel agency services, and many travel agency services in East Java Province try to defraud tourists by charging them a high price or asking them to pay excess costs when doing the trip.

On the other hand, we rarely found negative reviews related to accessibility in Jatim Park 2. This tourism site was considered to have high competitiveness in accessibility since tourists can easily come to Jatim Park 2 using public transportation, private transportation, or mass transportation like a bus. This accessibility was also enhanced with the operation time of Jatim Park from 10 am to $5 \mathrm{pm}$, which provides higher safety and accessibility than BTSNP or Ijen Crater. Despite having that advantage, Jatim Park 2 sometimes gets negative reviews due to traffic jams in Batu City during the high season (December-January and July). This disadvantage had prevented tourists from visiting Jatim Park 2 at particular times.

\section{Attraction}

Attraction in tourism destinations consists of natural, cultural, and artificial resources that have been used to attract tourists (Sunaryo, 2013). In 2018, there were 265 natural-based destinations, 320 cultural-based destinations, and 199 unique interest destinations in East Java Province (Bureau of Cultural and Tourism of East Java, 2019). Most of the tourism destinations in East Java Province are natural-based tourism, such as B TSNP and Ijen Crater. Usually, tourists visit this type of destination just once for hiking, sunrise seeking, and to get a photographic experience. Many tourist come to natural-based tourism on particular time like in dawn for sunrise or dusk for sunset. Because many of them considered natural-based tourism as monotonous tourism activity, only looking to the nature like sun, mountain, or forest without doing another tourism activity, which that can prolonged their leght of stay. This typical tourist behaviour potentially harms the destination environment due to many tourist shortcomings at a specific area and time that exceeds environment capacity.

However, special interest tourism like Jatim Park 2 has more advantages because they have various attractions and activities. Much artificial tourism in East Java has a high demand from tourists that come from various regions. The management and related stakeholders can spread the tourists to many areas and 
avoid them piling up in one particular area. The other type of negative review that needs more attention due to high negative sentiment is weather conditions in East Java Province. Many negative reviews related to attractions in East Java Province were due to rainy weather when they came to the tourism site. This review showed that most of the tourism destinations in East Java were dominated by outdoor tourism activity and greatly influenced by the weather. The related stakeholders need to consider this condition when developing a tourism destination in East Java Province.

\section{Informatics and Communication}

Information played a significant role in introducing the advantages of tourism destinations through social media (Heliany, 2019). Many tourists prefer to visit tourism destinations with information that is easy to find digitally, like on social media or websites. This advantage is caused by the matching search option of tourist preference on the internet (Gretzel et al., 2020). For example, tourism destinations were matched and classified by the budget, online ticketing, or practical trip when tourists travelled using a travel agency service.

Figure 4 is an analysis result graph called a word cloud, related to the information and communicationrelated category. In this figure, we found many significant keywords that often appear in the reviews, such as operational hours, guide, experience, location, price, worth, and ticket. The bigger the word in the picture, such as 'guide' or 'hours', means that everything related to that word, such as 'tour guide' or 'open hour,' has a more significant influence on the information and communication category.

Information transparency and good communication between government, tourists, investors, the local community, and tourism managers have significantly influenced East Java tourism competitiveness. Potential tourists can find information related to tour and travel agency services, tourism destination locations and their open hours, transportation and accommodation facilities, and other expenses they may need in the future, while the related stakeholder such as the local community and the businessmen around the tourism destination also need that information

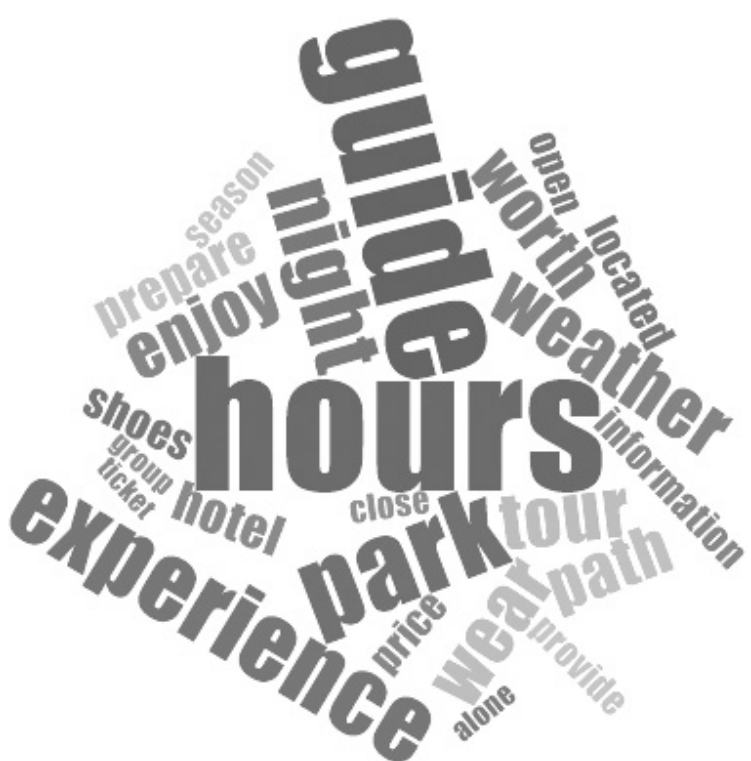

Figure 4 Word Cloud Information and Communication of East Java Tourism

to increase their economic activity by providing for tourism needs in the surrounding area.

In East Java, Jatim Park 2 and Ijen Crater are known as the tourism destinations that give trusted information through their official digital platforms such as their website and Instagram account. Both tourism destinations have adopted the tourism digitalization concept to facilitate tourists and stakeholders in terms of tourism agency and activity information. The Ijen Crater information can be accessed on the bayuwangitourism.com website while Jatim Park 2 information can be obtained on the jtp.id website. Both forms of digital media can provide information about online tickets, tourism activity, operational hours, accommodation, transportation, and nearby tourism destinations to the tourist candidate or related stakeholders.

In contrast, the B TSNP digital tourism information condition was worse than both of these. There was no official digital platform of B TSNP available to ourists, especially concerning the ticket, tourism activity, operational hours, or nearby tourism destinations. Usually, B TSNP information was provided by private travel agencies or individuals through social media, like vloggers or 'celebgrams' (famous users on Instagram). This condition drives tourists to gather 
the related information on their own to avoid the risk of money fraud when doing tourism activities like paying for overpriced products or services, horse-riding, and jacket renting in the B TSN P area.

\section{Institutional}

'Institutional' is known as the category related to the management party of tourism destinations, including human resources and the local communities near the destination, and private investors (Sunaryo, 2013). Jatim Park 2 was regarded to have the lowest competitiveness in institutional aspects due to the local community and minimum government participation in its development. Many tourists have written negative reviews of Jatim Park 2 institutional-related unfriendly employees that may harm tourist safety inside the destination because they do not want to hear or deal with tourist complaints reasonably.

Ijen Crater and в T SNP institutional conditions are different than those of Jatim Park 2. The local community participated significantly in tourism development, which caused either positive or negative sentiments. Some local communities developed tourism competitiveness positively through their friendly attitude, such as when local people try to greet tourists satisfactorily or try to keep the surrounding destination clean from tourism activity waste. Based on the research, Ijen Crater was known to have the highest institutional competitiveness due to local communities' creativity in providing culinary offers, like 'rawon,' grilled fish, and 'pecel.' In this aspect, the в T SN P destination has lower competitiveness, because most of the food around the BTSNP area was dominated by fried snacks and instant noodles that are easily found anywhere in East Java Province.

Related to negative sentiment, many tourists write their reviews about nasty behaviour that comes from the local community around tourism destinations. Many local people think of tourists as their gold mine, and scamming frequently happened in the tourism area. Local people insisted tourists purchase their overpriced products or services. For example, many local people in the BTSNP area force tourists to take a horse ride in Bromo Mount for hiking with an approximate price of $\mathrm{Rp} 150,000$. Similar conditions can be found in Ijen Crater. The local community insisted tourists to ride the trolley of sulphur carriers when climbing or descending Jaya Wijaya Peak (Ijen Mountain Peak) and calling this activity as 'Trolley Ride' with an approximate price of around $\mathrm{Rp} 250,000-\mathrm{Rp}$ 300,000 for every trip (climbing or descending). Low education is regarded as the significant factor in these poor manners, despite Ijen Crater's status as a prior tourism destination of East Java.

\section{Supportive Facilities}

Supportive facilities are the tourism competitiveness category that covers all public facilities, including security, toilets, tourism agencies, souvenir shops, information centres, banking facilities, restaurants, and others (Sunaryo, 2013). Jatim Park 2 is considered as a fully-supported facility tourism destination compared to the other two destinations. This statement was proved by the high number of positive sentiments (78.45\%) related to the review of supporting facilities in Jatim Park 2. Most of the positive reviews were about the hygienic toilets, proper parking site, and good management of Jatim Park 2. This fully provided facility has enhanced Jatim Park 2 as a family-themed park. Jatim Park 2 also has other facilities to meet the requirement of special needs consumers like pregnant women, toddlers, and seniors.

In contrast, many supportive facilities around $\mathrm{B}$ TSNP and Ijen Crater were severely damaged and unmaintained. The B TSNP and Ijen Crater development in the protected forest area was limited by Act No.5 of 1990 concerning Conservation of Living Natural Resources and Ecosystem. Because of this regulation, management and related stakeholders cannot freely develop and maintain B TSNP and Ijen Crater facilities. The most negative perspective reviews of $\mathrm{BT}$ SNP and Ijen Crater were about accommodation and amenities in the tourism area as shown in Figure 5. This figure highlights the words guide, toilets, jacket, mask, dollars (financial service), stalls, and lighting. These words significantly influence the supportive facilities category in B TSNP and Ijen Crater negatively or neutrally. The amount of в TSNP and Ijen Crater facilities were considered less accommodated and exceeded the tourist capacity. The amount of BTsnp and 


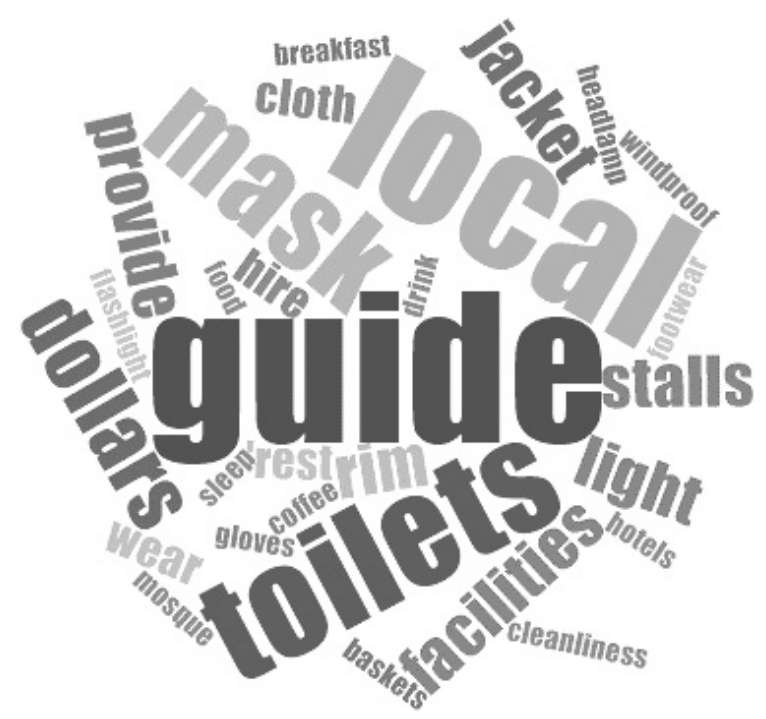

Figure 5 Word Cloud of Negative Ijen Crater and B TSNP Supportive Facilities Perspective

Ijen Crater suportive facilities only a few and located in certain area like rest area. Many tourist were considered this supportive facilities was not maintained, less accommodated and exceeded the tourist capacity. This condition worsened in peak season and at weekends. because the available facilities cannot accommodate too many tourists who usually come on holiday. Not only that, в TSNP and Ijen Crater amenities and accommodation were considered expensive due to the lack of supportive facilities like clean water supply in the surrounding areas.

Wibowo (2020) stated that the sanitary and culinary facilities of the B TSNP area were preserved at a high cost due to a lack of clean water sources. As a result, the local community needs to purchase water at a very high price to meet tourist demand in the в тSNP area. This similar condition was also found in the accommodation facilities in Cemorolawang (an area nearby). Many tourists complained about the highcost hotels with unclean and unmaintained rooms and toilets in their reviews. This condition can be considered as one factor that can affect tourism competitiveness negatively in the long run. Due to this condition, many tourists refuse to revisit the B TSNP tourism site and seek new tourism destinations with proper facilities surrounding the tourism site.

\section{East Java Province Sustainable Tourism}

Recommendation

Based on findings in this study, there are a few recommendation policies that can be applied to enhance tourism competitiveness in East Java Province, as follows:

\section{Tourism Business Levelling}

Levelling is defined as business capacity increment activity, especially msmes (micro, small, and medium enterprises) owned by the local community surrounding the tourism site. According to the needs of local community businesses, levelling activity of business activity in tourism sites is provided through training or business incubation activities. These activities aim to improve tourism competitiveness through the following aspects:

- The community would be able to manage business more professionally, including human resource management, production management, financial management, etc.

- By introducing new innovations and technology uses, the local community should be able to increase their business capacity and attract more consumers, especially tourists.

- Business owners would be able to expand their business network to find investors more easily.

- The well-maintained businesses surrounding the tourism area will enhance tourism competitiveness, especially in the accessibility category. This condition will also give a multiplier effect to the local community that previously never got the positive impact of tourism activity.

- Positive economic activity surrounding the tourism area will eventually attract investors that have an interest to maintain and improve supportive facilities and services. The investment is usually in the form of CSR (corporate social responsibility) programmes, training classes, or other activities.

\section{Local Common Brand Development}

The tourism activity in East Java Province is unique and makes it different from other tourism sites. The 
uniqueness of East Java tourism sites and activity must be highlighted through branding and promotion activity. In tourism research and development strategies and practices, branding and promotion are known as the potential strategy in tourism sectors and can be used to support sustainable tourism activity in East Java Province. The related stakeholders can make East Java Province tourism well and widely known through branding and promoting activities, thus attracting interested tourists to find out more about tourism in East Java Province.

East Java Province brand development might be done through cultural and arts potential exploration. Well explored and utilized cultural and arts potential can create a positive tourism brand in East Java Province. This term means that tourism brands integrate technology with the characteristic local philosophy of East Java tourism. The brand output is formed in the online product such as digital content or physical products such as souvenirs, product packaging, posters, flyers, and other promotional products

\section{Local Tourism Integration}

Sustainable tourism development of East Java Province will cause a high multiplier effect in certain areas. The multiplier effect is able to increase the inclusive and sustainable economic activity of the local community. One effect is local business integration for each tourism destination to maximize tourism resource potential. This local tourism integration programme of East Java Province can be achieved through the collaboration of regional government, village government, and youth communities (karang taruna) near to tourism sites.

\section{Supporting Cashless Transactions}

Monetary facilities have become a matter of issue in the tourism competitiveness of East Java. Through financial literacy support, tourism economic activity could be improved, becoming more effective, safe, and remotely accessible. Cashless transactions would enhance the digital payment environment. This concept is supported with an online system to facilitate tourism activity for each party, such as estimating the cost for tourists, determining the number of tourists for stakeholders, tourist number management for the management party, and transaction of MSMEs. Recently, there have been digital platforms that can facilitate financial transactions in East Java tourism destinations to make them more efficient and safe, such as QRIS, GO-PAY, ovo, and DANA.

\section{Conclusion, Limitation, and Suggestions} Conclusion

Following are the conclusions of this research about sustainable tourism competitiveness of East Java Province:

1. The number of tourists in East Java Province has increased annually, even though commonly only one tourism destination is visited before leaving East Java Province, like Bali Island and Yogyakarta

2. According to the perspective analysis about East Java tourism competitiveness, Ijen Crater is the most competitive tourism destination, followed by Jatim Park 2, then BTSNP. Artificial or particular interest tourism destinations have high potential to be developed in East Java Province through attraction exploration due to their competitiveness among nature-themed tourism destinations.

3. According to perspective analysis results about East Java Province competitiveness, the following four recommended policies were obtained to improve competitiveness and local economic activity near tourism destinations:

- Tourism business levelling;

- East Java Province local common brand development;

- Local tourism integration;

- Supporting cashless transactions.

\section{Limitations}

This article has limitations. First, we only obtained data from the TripAdvisor site. Another limitation is that we manually classified every review in the sentiment category. This process is time-consuming and might influence the efficiency of characterizing crisis 
information sharing. In the future, we will try to obtain a larger amount of data from a similar site like Google Flights or Expedia to get a better insight. Not only that, we also plan to apply automatic labelling methods to avoid this limitation.

\section{Suggestions}

Based on the conclusion and limitations above, we have two suggestions. First, trying to conduct a further study about local community participation and institutional perspective to improve East Java Province tourism competitiveness. Second, supposing the further research attempts to use the same sentiment analysis method, we suggest applying automatic labelling methods to ensure time efficiency while doing the research.

\section{References}

Aprilia, F., Kumadji, S., \& Kusumawati, A. (2015). Pengaruh word of mouth terhadap minat berkunjung serta dampaknya pada keputusan berkunjung. Jurnal Administrasi Bisnis, 24(1), 1-6.

Aydin, G. (2020). Social media engagement and organic post effectiveness: A roadmap for increasing the effectiveness of social media use in hospitality industry. Journal of Hospitality Marketing and Management, 29(1) 1-21.

Bandur, A. (2016). Penelitian Kualitatif: Metodologi, Desain, dan Teknik Analisis Data dengan NVIvo 11 Plus. Mitra Wacana Media.

Bank Indonesia. (2020). Roadmap Pengembangan Wisata Alam Taman Nasional Bromo Tengger Semeru. Malang.

Blanco-Cerradelo, L., Gueimonde-Canto, A., Fraiz-Brea, J. A., and Diéguez-Castrillón, M. I. (2018), Dimensions of destination competitiveness: Analyses of protected areas in Spain, Journal of Cleaner Production, 177, 782-794.

Bureau of Cultural and Tourism of East Java. (2019). Rencana strategis pengembangan pariwisata Jawa Timur 20182024. Surabaya.

Central Statistics Agency of East Java Province. (2019). Perkembangan pariwisata Jawa Timur Maret 2019. Surabaya.

Chen, C. M., Chen, S. H., Lee, H. T., \& Tsai, T. H. (2016). Exploring destination resources and competitiveness: A comparative analysis of tourists' perceptions and satisfaction toward an Island of Taiwan. Ocean and Coastal Management, 119, 58-67.

Chin, C.-H., Lo, M.-C., Songan, P, \& Nair, V. (2014). Rural tourism destination competitiveness: A study on Annah
Rais Longhouse Homestay, Sarawak. Procedia: Social and Behavioral Sciences, 144, 35-44.

Giglio, S., Bertacchini, F., Bilotta, E., \& Pantano, P. (2019). Using social media to identify tourism attraction in six Italian cities. Tourism Management, 72, 306-312.

Gretzel, U., Fuchs, M., Baggio, R., Hoepken, W., Law, R., Neidhart, J., Pesonen, J., Zanker, M., \& Xhiang, Z. (2020). Etourism beyond COVID-19: A call for transformative research. Information Technology and Tourism, 22(2), 187203.

Gretzel, U., Reino, S., Kopera, S., \& Koo, C. (2015). Smart tourism challenges. Journal of Tourism, 16(1), 41-47.

Hassan, S. S. (200o). Determinants of market competitiveness in an environmentally sustainable tourism industry. Journal of Travel Research, 38(3) 239-245.

Heliany, I. (2019). Wonderful digital tourism Indonesia dan peran revolusi industri dalam menghadapi era ekonomi digital 5.o. Destinesia: Jurnal Hospitaliti dan Pariwisata, 1(1): $21-35$.

Hussein Jaddou, H. (2007). Marketing of a destination [Unpublished $\mathrm{PhD}$ dissertation]. University of Huddersfield.

Kusumasari, D., \& Rafizan, O. (2018). Studi implementasi sistem big data untuk mendukung kebijakan komunikasi dan informatika. Masyarakat Telematika Dan Informasi: Jurnal Penelitian Teknologi Informasi dan Komunikasi, 8(2), 81-96.

Li, J., Xu, L., Tang, L., Wang, S., \& Li, L. (2018). Big data in tourism research: A literature review. Tourism Management, 68, 301-323.

Menk, A., Sebastia, L., \& Ferreira, R. (2018). Curumim: A serendipitous recommender system for tourism based on human curiosity. In International Conference on Tools with Artificial Intelligence (pp. 788-795). IEEE Computer Society.

Minciu, R., Popecsu, D., Padurean, M., Hornoiu, R., \& Baltaretu, A. (2010). Commercialization of holidays in the protected natural areas. Form of the sustainable development in tourism. Amfiteatru Economic, 12(27), 83-98.

Ministry of Communication and Informatics. (2019, 26 September). Gubernur: Jatim bagian the awakening giant ekonomi Indonesia. http://kominfo.jatimprov.go .id/read/umum/gubernur-jatim-bagian-the-awakening -giant-ekonomi-indonesia

Ministry of Tourism and Creative Economy. (2020). Laporan kinerja kementerian pariwisata tahun 2019.

Mohamed, N., \& Al-Jaroodi, J. (2014). Real-time big data analytics: Applications and challenges. In International Conference on High Performance Computing and Simulation (pp. 305-310). IEEE. 
Nanda, A. D. (2018). Perencanaan perkuatan tanah untuk pelabuhan kapal pesiar Zona B Marina Boom Banyuwangi. [Unpublished $\mathrm{PhD}$ dissertation]. Institut Teknologi Sepuluh Nopember.

Nestoroska, I. (2012). Identifying tourism potentials in Republic of Macedonia through regional approach. Social and Behavioral Sciences, 44, 95-103.

Nurhidayati, S. E. (2009). Sistem pariwisata di agropolitan Batu. Media Masyarakat, Kebudayaan dan Politik, 22(1), 76-85.

Pavlic, I., Portolan, A., \& Puh, B. (2019). Does tourism cut the branch it is sitting on? Local residents' perspective. Montenegrin Journal of Economics, 15(2), 153-164.

Poerwanto, P., and Shambodo, Y. (2020). Revolusi industri 4.0: Googelisasi industri pariwisata dan industri kreatif. Journal of Tourism and Creativity, 4(1), 59-72.

Praveen, S., \& Chandra, U. (2017). Influence of structured, semi-structured, unstructured data on various data models. International Journal of Scientific \& Engineering Research, 8(12), 67-69.

President of the Republic of Indonesia. 2019. Article 80 year 2019 economic development acceleration in Gresik-Bangkalan-Mojokerto-Surabaya-Sidoarjo-Lamongan, BromoTengger-Semeru Area, and Wilis Circular Area and South Highway Area.

Putra, F. K. K., Saepudin, P., Adriansyah, E., \& Wahyu Adrian I. (2018). Digital tourism: A content analysis of West Java tourism webdsites. Journal of Indonesian Tourism and Development Studies, 6(2). 73-84.

Rachmat, A., and Y. Lukito. (2016). SEn T I P OL: Dataset Sentimen Komentar Pada Kampanye pe milu Presiden Indonesia 2014 Dari Facebook Page. In Konferensi Nasional Teknologi Informasi Dan Komunikasi (pp. 218228). sтмік Budi Darma.

Sabiote-Ortiz, C. M., Frías-Jamilena, D. M. and CastañedaGarcía, J. A. (2016). Overall perceived value of a tourism service delivered via different media: A cross-cultural perspective. Journal of Travel Research, 55(1), 34-51.

Sari, R. (2020). Analisis sentimen pada review objek wisata dunia fantasi menggunakan algoritma K-Nearest Neighbor (K-NN). Evolusi: Jurnal Sains dan Manajemen, 8(1), $10-17$.

Sasidharan, V., \& Krizaj, D. (2018). Tourism ecolabels and social sustainability: Challenges and innovations from a Slovene perspective. Academica Turistica, 11(1), 19-29.

Saura, J. R, Reyes-Menendez, A., \& Alvarez-Alonso, C. (2018). Do online comments affect environmental management? Sustainability 10(9), 1-20.

Schuckert, M., Liu, X., \& Law, R. (2015). Hospitality and tourism online reviews: Recent trends and future directions. Journal of Travel and Tourism Marketing, (August), 608-621.

Sowmya, R., and K. R. Suneetha. (2017). Data mining with big data. In Proceedings of 11th International Conference on Intelligent Systems and Control (pp. 246-250). International Journal of Innovation.

Suanpang, P. (2020). Factor analysis of using social media in tourism enterprises for competitiveness. International Journal of Innovation, Management and Technology, 11(1), 27-32.

Subarkah, A. R. (2018). Potensi dan prospek wisata halal dalam meningkatkan ekonomi daerah. Jurnal Sosial Politik, 4(2), 49-72.

Suhato, B. (2016). Strategi pengembangan wisata agro di Banyuwangi. Jurnal Ilmiah Pariwisata, 21(1), 1-15.

Sun, P., Cárdenas, D. A., \& Harrill, R. (2016). Chinese customers' evaluation of travel website quality: A decisiontree analysis. Journal of Hospitality Marketing and Management, 25(4), 476-497.

Sunardi, N. R., \& Estikowati. (2019). Analysis of sustainable tourism development in Bromo Tengger Semeru national park. Journal of Southwest Jiaotong University, 54(6), 1-12.

Sunaryo, B. (2013). Kebijakan pembangunan destinasi pariwisata: konsep dan aplikasinya di Indonesia. Gava Media.

TripAdvisor. (2020a). Batu secret zoo (Jawa Timur park 2). https://www.tripadvisor.com/Attraction_Review -g1237079-d1997282-Reviews-Batu_Secret_Zoo_Jawa _Timur_Park_2-Batu_East_Java_Java.html.

TripAdvisor. (2020b), Things to do in East Java. https://www .tripadvisor.com/Attractions-g2301797-Activities-East _Java_Java.html

Tsaur, S. H., Lin, Y. C., \& Lin, Y. H. (2006). Evaluating ecotourism sustainability from the integrated perspective of resource, community and tourism. Tourism Management, $27(4), 640-653$.

Tung, L. T. and Cuong, L. K. (2020). Impact of tourism on poverty reduction: Evidence from an emerging tourism market. Montenegrin Journal of Economics, 16(3), 45-55.

UNW TO. (2020). Priorities for tourism recovery. https:// webunwto.s3.eu-west-1.amazonaws.com/s3fs-public /2020-05/UNWTO-Priorities-for-Global-Tourism -Recovery.pdf

Wibowo, J. M., Muljaningsih, S., \& Satria, D. (2019). Tripadvisor sentiment analysis: The policy of ecotourism competitiveness from Bromo, Tengger, and Semeru national park. International Journal of Business, Economics and Law, 20(5), 18-24. 
Wibowo, J. Mi. (2020). Studi Daya Saing Ekowisata Berkelanjutan Taman Nasional Bromo Tengger Semeru [Unpublished $\mathrm{PhD}$ dissertation]. Univesitas Brawijaya.

Xiang, Z., Du, Q., Ma, Y., \& Fan, W. (2017). A comparative analysis of major online review platforms: Implications for social media analytics in hospitality and tourism. Tourism Management, 58, 51-65.

Yanti, D. 2019. Analisis strategi pengembangan digital tourism sebagai promosi pariwisata di Toba Samosir. Jurnal Darma Agung, 27(April), 814-821.
Ye, Q., Zhang, Z., Law, R. (2009). Sentimen classification of online reviews to travel destinations by supervised machine learning approach. Expert System with Applications, 36(3 Part 2), 6527-6535.

Zhang, H., Gu, C. L., Gu, . W., \& Zhang, Y. (2011), The evaluation of tourism destination competitiveness by TOPSIS \& information entropy: A case in the Yangtze river delta of China. Tourism Management, 32(2), 443-451. 